area for wildlife the year around.

On October 3rd and 4th, I again saw Ross' Geese on Last Mountain Lake, west of Govan, though in somewhat fewer numbers than those observed on September 27. This may simply mean that I was not in an area where the majority were resting. John Hatfield, Project Manager of the Last Mountain Lake Wildlife Refuge, has since told me that he also observed unusually large numbers of Ross' Geese at the north end of the lake from September 20 to October 10, 1970. Most of the geese left the area October 8 during a weather front moving in from the northwest with strong, gusty winds.

I was aided in the identification of the Ross' Geese by their call which is quite distinctive from that of the other species, and I was fortunate enough to obtain a tape recording of their voices.

\section{POSSIBLE WILD HYBRID OF THE WHITE-FRONTED $X$ SNOW GOOSE}

by F. W. Lahrman, Saskatchewan Museum of Natural History, Regina

On October 4, 1970, while observing geese and cranes at the north end of Last Mountain Lake, northwest of Govan, I noticed a strange colored goose flying with a flock of approximately 35 White-fronted Geese around 10:00 a.m. The flock alighted on a stubble field only one-quarter of a mile away, where I was able to observe this goose with a $30 \mathrm{x}$ telescope. On checking later, I was surprised to note that it had a marked similarity to the two geese described by Alex Dzubin of the Canadian Wildlife Service (Blue Jay, $22: 101-107$ ).

\section{Description of the Goose}

Silhouette, size, head, bill, neck and body proportions appeared to be similar to that of the White-fronts; bill orange; head and neck - dark gray; broad white forehead patch and a light cheek patch. The gray of the neck fused into a white breast near the base of the neck; entire underparts-white. The back from base of tail almost to base of wings - white (observed when bird was in flight). At rest, the bird appeared to be gray above and white below. The tail was dark gray. The wings appeared to be similar to those of the White-fronts. I was unable to see the color of the legs or to determine whether it had a dark grinning patch on the bill such as the Snow Geese have.

I do not think that this was a partial albino White-front because the darker colors were slate-gray rather than the gray-brown of the Whitefronts.

Several Snow and Blue Geese were observed in the area but they were not associated with this flock.

\section{Information Wanted on Colour-marked Bald Eagles}

As part of a project designed to learn more about the migration of Saskatchewan's Bald Eagles, the tails of 16 nestlings were painted orange this past summer. If you see or hear of one of these marked eagles, please contact D. Whitfield, 415 10th Street E., Saskatoon.

\section{FIELD NOTES REPORTS}

The new regional editor for AUDUBON FIELD NOTES is C. Stuart Houston, 863 University Drive, Saskatoon. All birdwatchers on the prairies are asked to submit their seasonal observations regularly to allow an overall picture of bird distribution and abundance. Notes on the common species with dates and numbers are more desirable than observations of rarities. Data on fall migration are due December 10, winter season April 10, spring migration June 10 and nesting season August 10.

\section{NEST RECORD CARDS}

Please send Prairie Nest Record Cards in to the Prairie Nest Records Scheme, c/o The Manitoba Museum of Man and Nature, 190 Rupert Avenue, Winnipeg 2, Manitoba, as soon as possible, so that the 1970 summary can be prepared. 